\title{
TRAINING OF THE EDUCATORS OF PRESCHOOL EDUCATIONAL INSTITUTIONS TO THE AUTHENTICITY FORMATION OF THE PRESCHOOLERS
}

\author{
Halina Nazarenko \\ Vice Rector \\ MEI «Cherkasy Regional Institute of Postgraduate education of \\ Teachers of the Cherkasy Regional Council»" \\ 38/1 Bydgoschska str., Cherkasy, Ukraine, 18003 \\ nagaan@ukr.net
}

\begin{abstract}
The development of the personality-oriented model of the Ukrainian education system based on the principle of child-centeredness, maximum consideration of the abilities, needs and interests of each child, its age-specific features of physical, mental and mental development actualizes the problem of the formation and development of authenticity of preschoolers. The essence of the author's technology of authenticity facilitation of the preschooler's personality as a system of scientifically substantiated procedures for the gradual development of the educational process in the unity of content, principles, methods, forms, organizational and pedagogical conditions for the interaction of its subjects, the purpose of which is the ability of the preschooler's personality to live in harmony with its inner world, to act without changing your true "I". The technology is aimed at helping each child to realize itself as a self-worth, knowledge of its capabilities and natural potential in all spheres of life. The totality of the motivational-value, cognitive, operational and reflexive-personal criteria and their corresponding indicators for diagnosing the level of readiness of teachers of pre-school education institutions to form the authenticity of pupils are presented. The results of approbation of the author's elective course for the system of postgraduate pedagogical education "Theoretical and practical bases for the authenticity formation of preschoolers" are presented for the training of teachers of pre-school institutions for the effective implementation of this process.
\end{abstract}

Keywords: preschooler, authenticity, pedagogical facilitation, teacher training, authoring technology.

\section{Introduction}

The concept of the New Ukrainian School directs the efforts of Ukrainian educators to build a personally oriented educational model, according to which the abilities, needs and interests of each child are taken into account, the principle of child-centeredness is realized in practice. Teachers are faced with the task of maximizing the education and upbringing in the essence of each child in accordance with its individual styles and educational needs. It is noted that educational activity must be organized taking into account the age features of the physical, mental and mental development of children, based on the personalization (individualization) of their personal experience [1].

In this context, the educational line "The Personality of the Child" of the Basic component of preschool education contains the requirement to educate the child of a positive attitude toward its appearance, the formation of "I" positive image of the in the preschool child, the creation of the child's personal culture and active life. At the same time, the activities of educators of pre-school education institutions should be directed to the formation of such important signs of the preschoolers' authenticity as self-awareness, a positive "I-concept," self-reliance, self-esteem, personal dignity. It is presumed that as a result of such educational influence the preschool child will be aware of the existence of its inner world (its own thoughts, feelings, desires, attitudes), be aware of its preferences, attachments, interests, orient in its basic emotions and feelings, know what he wants (or not wants), and also can substantiate its attitude to itself, other people, life events and phenomena of the surrounding environment [2]. The above mentioned actualizes the problem of the formation and development of the preschooler's authenticity.

The successful solution of the problems of the authenticity formation of preschoolers depends to a large extent on the level of willingness of the educators to carry out activities in this aspect. We uphold the thesis that in the conditions of humanization and individualization of modern education, the willingness of the teacher of the preschool education institution to form the pre- 
schoolers' authenticity is one of the important components of professional readiness, the prerequisite for the effective organization of the investigated process, the maximum realization of their capabilities and the disclosure of creativity in this aspect.

It should be noted that the problem of training teachers to effectively solve modern educational problems is in the field of vision of many researchers in postgraduate pedagogical education. In particular, the scientific works of recent years have highlighted innovative technologies and methods of professional teacher education [3], the theoretical foundations of professional pedagogical self-realization of teachers [4], the foundations of professional self-improvement of the teacher as a subject of self-discovery activity [5], comprehensively investigated the problems of the development of professionally pedagogical qualities of teachers in the system of continuous education [6], teacher training in the system of postgraduate pedagogical education to the design of teaching technologies [7], the formation of professional competence of the modern educator of preschool educational institutions [8].

Without detracting from the importance of the scientific works of the above mentioned and other scientists, let's note that the problem of training teachers for the authenticity formation of a preschool child has not been the subject of scientific research so far.

\section{Aim of research}

Coverage of the essence of the author's technology of facilitation of the authenticity formation of the preschooler's personality, as well as the author's course for the system of postgraduate pedagogical education for the training of pre-school educators for the authenticity formation of preschoolers.

\section{Materials and methods}

To participate in the pilot work, which took place during 2016-2017, educators of pre-school education institutions were involved, who studied at the courses of advanced training in the communal educational institution "Cherkasy Regional Institute of Postgraduate Education Teaching Staff of the Cherkasy Regional Council” (total 257 people). At the stage of theoretical comprehension of the investigated problem, methods of analysis of scientific and pedagogical literature, systematization and generalization of theoretical data, content analysis of normative and legal documents on pre-school education were used. In the course of the research methods of pedagogical diagnostics (questioning, testing, self-assessment, expert assessments) and methods of mathematical statistics for quantitative and qualitative analysis of the obtained results were also used. The pedagogical experiment was chosen as the main method of investigation.

\section{Result and discussion}

Experimental work is directed to the study of the content and methodology of training educators of pre-school institutions for the authenticity formation of preschoolers.

At the conceptual and diagnostic stage of the experimental work, author's technology of facilitation of the authenticity formation of the preschooler's personality and the author's training course for educators of pre-school institutions for the authenticity formation of preschoolers are developed.

First, on the basis of theoretical analysis, it is found that the term "authenticity" is introduced into the scientific revolution by representatives of existential-humanistic psychology. In the scientific works of representatives of this direction [9-12] it is noted that authenticity is a condition for the acquisition by the individual of identity as coherence with its inner nature, provides for a specific life path with an individual and personal search for the purpose and meaning of life, a strategy for building one's own existence.

An analysis of the scientific works of these scientists became the basis for the conclusion that an authentic person is a person who understands itself, its desires, possibilities, needs and abilities; which feels its worth, understands the meaning of its existence, fully functions, lives by its own convictions, is free and complete [10]; self-actualized personality, which realizes who it really is, what it wants and what it vocation, destiny or purpose is; understands its inner nature and 
seeks to realize it in its own vital activity [9]; a person who is able to fully live without changing its true "I" [12]. At the same time, the formation and development of the personality authenticity is linked by the named scientists with the help of a person to feel their inner essence ("self"), the individual peculiarity of the tasks of their own existence, to realize their desires, thoughts, emotions, feelings, abilities and potential opportunities (their real "I", which would ensure a full life of the person in harmony with inner nature.

The essence of the own developed technology is based on the principled position that in the preschool childhood of the authenticity formation as the ability of a growing personality to live in harmony with its inner world, to act without changing its true "I" only begins and requires pedagogical facilitation.

Let's consider it advisable to note that the author of the term "facilitation" (from English to facilitate - to help, create favorable conditions) K. Rogers interpreted it as support, assistance and at the same time stimulation by the teacher of the process of becoming a personality-subject of one's own life, functioning and personal growth [10].

The technology of the pedagogical facilitation of the authenticity formation of the preschooler's personality is viewed as a system of scientifically grounded procedures for the phased deployment of the educational process in the unity of content, principles, methods, forms, organizational and pedagogical conditions for the interaction of its subjects [13], which is directed to help each child in self- knowledge of their capabilities and potential opportunities in all spheres of life, the realization of the pupil of its natural potential as signs of the authenticity of an enlightened person. In turn, let's interpret pedagogical facilitation as a joint search for and interaction between the educator and the preschooler, aimed at coordinating external influences with the internal properties of the pupil's personality, which provides changes in its consciousness and behavior, and leads to active efforts to disclose its own internal potencies. At the same time, each subject of facilitative interaction is recognized as a unique person, equal among others in the manifestation of its individuality.

The own developed technology is aimed at facilitating the formation and development of such important signs of the preschooler's authenticity as self-awareness, in particular, the development of the child's adequate identification with its "I", the ability to find common and different among themselves and others, the formation of self-reliance and opportunities, the ability to navigate in their virtues and vices, the ability to exercise self-esteem and dignity, to relate their desires and opportunities.

This is achieved through the implementation of program-targeted, subject-activity and personality-oriented approaches, which allows to provide a comprehensive and systemic humanization and personal orientation of educational interaction, based on recognizing the child as unique, filled with different aspirations and interests of the subject, providing real manifestations of the essential nature of the authentic personality preschooler, taking into account its individual characteristics, interests and needs [11].

Pedagogical facilitation of the formation and development of the authenticity of the preschooler's personality requires the approval of the relationship of positive emotional support and psychological protection of the child and is based on understanding, recognition and acceptance of the pupil (according to I. Bech):

- understanding of the child assumes the teacher's ability to correctly assess its emotional state, the ability to perceive and adequately interpret the pupil's behavior directly at each moment of communication; it is empathic awareness of the whole controversial "I" of the pupil, the ability to listen and, most importantly, to hear and understand it;

- recognition of the child means the realization of its right to be itself, unlike other individuals, unique in the sense that it is only inherent in its naturally set temperament, character, makings that determine the specificity of its interests, needs, abilities; this awareness of the uniqueness, autonomy, sovereignty, independence of the individual, its right to its own way of life;

- adoption of the child means an unconditional positive attitude towards it as it is, with all its inherent qualities; it is attention to the feelings and thoughts of the preschooler. Adoption of the child assumes respect for the child's personality and is manifested in sympathy, goodwill 
and sincerity of relationships, which contribute to the self-knowledge and personal growth of the pupil [11].

At the conceptual and diagnostic stage of the experiment, ascertaining is diagnosed the readiness of educators to form the preschoolers' authenticity, and an author's training course for educators of pre-school institutions is developed to form the preschoolers' authenticity.

First of all, let's note that readiness for the authenticity formation of preschoolers is viewed as an integrated quality of the educator's personality, which includes in its structure the necessary knowledge, skills, qualities, abilities, manifests itself in an active professional pedagogical position and presupposes the existence of a motivational and value attitude to activities in this aspect possession of effective ways and means to achieve the goals of the authenticity formation of preschoolers, the ability to professionally personal reflection in this aspect [14].

Diagnostics of teachers' readiness for the authenticity formation of preschoolers is carried out with the help of motivation-value, cognitive, operational and reflexive-personal criteria and corresponding indicators.

The motivation-value criterion of readiness for the authenticity formation of preschoolers expresses the educator's conscious attitude to the indicated problem and its importance in the formation of the personality of the pupil.

Indicators of the motivation and value criterion of readiness for the authenticity formation of preschoolers is the awareness of the need to implement this process, the socially significant motives of the teacher's activity in shaping the preschoolers' authenticity; the cognitive interest of the teacher in various aspects of this process, the value attitude to such activities and value orientations in the aspect of the formation of the preschoolers' authenticity (the system of beliefs, ideals, aspirations, attitudes and ethical principles of pedagogical interaction based on humanistic pedagogical values).

The cognitive criterion of the teacher's readiness for the authenticity formation of preschoolers unites the totality of the teacher's conscious knowledge about the essence and specifics of this process, as well as the system of general pedagogical, subject and special knowledge necessary for realizing the tasks of forming the preschoolers' authenticity. Its indicators are informed knowledge:

- the essence of preschoolers' authenticity;

- theoretical foundations for the authenticity formation of preschoolers;

- age features of preschoolers;

- the essence of the technology of pedagogical facilitation of the authenticity formation of the preschooler's personality.

The operational criterion of the teachers' readiness for the authenticity formation of preschoolers is represented by a complex of skills in the application of modern pedagogical technologies for the education of this quality, namely:

- gnostic (the ability to extract, replenish and expand their knowledge on the problem of the authenticity formation of preschoolers, to study the dynamics of the formation of this quality of the personality of the pupil);

- project (the ability to plan the process of authenticity formation of preschoolers in accordance with the objectives, content and methods of professional activity in this aspect);

- constructive (the ability to choose the optimal methods and forms of the authenticity formation of preschoolers, the ability to optimally implement the facilitation of the investigated process);

- organizational (the ability to organize pedagogical interaction in accordance with the goals of the process of the authenticity formation of preschoolers);

- communicative (the ability to establish interpersonal relations of all subjects of the process of the authenticity formation of preschoolers, prevent and overcome conflicts and create a communication network) [15].

Reflexive-personal criterion of the teacher's readiness for the authenticity formation of preschoolers reflects the skills and abilities of the analysis of the educational process; the ability to anticipate possible needs and problems, skills of self-control and self-esteem, the ability to objectively relate the level of self-preparedness to the authenticity formation of preschoolers. 
Indicators of the reflexive-personal criterion are defined: the recognition of strong and weak aspects of one's own readiness to carry out the authenticity formation of preschoolers; system of personal qualities and abilities of the teacher, allowing the optimal solution of the investigated problem.

Diagnostics on motivational-value, cognitive, procedural and reflexive-personal criteria in the aggregate allows to reveal the initial level of the teachers' readiness for the authenticity formation of preschoolers. In accordance with the results of the diagnosis, an author's training of educators is developed for the authenticity formation of preschoolers, aimed at the effective organization of the investigated process.

At the forming stage of experimental work at the advanced training courses, the optional course "Theoretical and practical bases for the authenticity formation of preschoolers" is developed. Approbation of the course, calculated for 24 hours (0.8 ECTS credits), took place by successive mastery of three modules: motivational-value, content-procedural and control-analytical.

Thus, mastering the motivational-value module of the elective course contributes to the awareness of the relevance of the authenticity formation problem of preschoolers in conditions of humanization of public life in Ukraine; content of the main regulatory legal acts on the organization of the investigated process; essence and structure of the concept of "preschoolers' authenticity".

This is facilitated by consideration of such topics of the author's course as: "Humanization of public life in Ukraine as a factor in the individual authenticity formation", "The problem of the authenticity formation of preschoolers in normative documents on pre-school education", "The theoretical basis for the authenticity formation of preschoolers", "age features of preschoolers", "The essence and structure of the preschoolers' authenticity", "Self-awareness and identity as components of the preschoolers' authenticity".

Training in accordance with the content-procedural module of the elective course ensures awareness of the methodological basis for the authenticity formation of preschoolers by educators of pre-school institutions; mastering the technology of pedagogical facilitation of the emergence of the identity of the preschooler; training analytical, prognostic, design, constructive, organizational, communicative and perceptual skills of the teacher, necessary for the successful organization of the process of the authenticity formation of the preschooler; consideration of the facilitation specifics of the authenticity formation of the child's personality.

For this purpose, workshops were held on the topics: "Features of the implementation of program-targeted, subject-activity and personality-oriented approaches to the authenticity formation of preschoolers", "The technology of pedagogical facilitation of the authenticity formation of preschooler", "Psychological foundations for establishing an atmosphere of positive emotional support and child protection", "Modern approaches to the formation of a positive "I-concept" of preschooler", "The methodology of education of the preschooler's confidence in their own abilities and capabilities, self-esteem, self-worth", "Features of planning the process of authenticity formation of preschoolers".

In the first part of the practical classes on the program of this elective course, a discussion of scientific and methodical works on the problem of authenticity formation of preschoolers is held by pre-school teachers. This contributed to the formation of pedagogical workers' ability to optimally manage this educational process. Particular emphasis is placed on the need to use modern approaches to planning the process of the authenticity formation of preschoolers, the appropriate selection of methods, forms and means of forming this phenomenon.

Considerable attention is paid to the lessons of the author's optional course on mastering the methods of creating educational situations for the authenticity formation of preschoolers, development of the ability to create an atmosphere of psychological comfort, and to study the dynamics of the authenticity formation of preschoolers.

To this end, the second part of each of these practical classes is conducted in the form of a business game. The method of conducting is in the practical mastering of various innovative forms of the authenticity formation of preschoolers, separate groups of educators are formed, who received tasks to prepare and present a new form of work or activity that would contribute to the authenticity formation of children. Teachers of each group independently distribute roles in their 
team, model the functions of each business participant and after self-training present for their other colleagues the practical use of the mastered form of work.

At the final stage of such lesson, the potential possibilities of the proposed forms of work and activities for the authenticity formation of preschoolers are discussed. In addition, each teacher receives assignments for independent work - to develop classes on the problem of the authenticity formation of preschoolers. During the briefing, the attention of teachers is drawn to the need for an optimal formulation of the goals and objectives of the lesson; expedient content and methods of joint interaction of the educator and preschoolers; interesting, non-standard and productive forms of work, running out the results of the session in the context of the authenticity formation of preschoolers.

The control and analytical module of the elective course provides for the exchange of experience in the authenticity formation of preschoolers and the conduct of control diagnosis, which shows a positive dynamics in the preparedness level of pre-school educators for the implementation of this educational process.

In their questionnaires, the tutors note that during the training on the elective course "Theoretical and practical bases for the authenticity formation of preschoolers" they master the ability to make the optimal selection of forms, methods and means of forming the authenticity of their pupils, learned to create the necessary moral and psychological conditions for this, to activate the personality of the child as a subject of joint educational interaction.

After completing the training on the author's optional course, the educators receive an electronic case containing materials on the problem of the authenticity formation of preschoolers for independent development, multimedia presentations on the subject matter, a list of recommended literature and links to electronic resources of the Internet. It should be noted that the electronic case for independent work not only provides tutors of pre-school education facilities the opportunity to repeatedly apply the provided methodological materials in a comfortable mode and pace, but also strengthens the motivation for their active use in practical activities.

\section{Conclusions}

The study provides grounds for such conclusions:

1. During the reform of the Ukrainian education system, the establishment of a personality-oriented model of educational activity based on the personalization of the child's personal experience, the problem of the authenticity formation of preschoolers acquires special significance.

2. The author's technology of pedagogical facilitation of the authenticity formation of preschoolers to promote the child's awareness of its inner world, its own abilities and potential opportunities that fundamentally distinguish its personality from all and contribute to its successful life.

3. Training of educators of pre-school education institutions on the author's course for the system of postgraduate pedagogical education "Theoretical and practical bases for the authenticity formation of preschoolers" ensures their full preparation for the formation and development of the preschoolers' authenticity.

\section{References}

[1] Kontseptsiia novoi ukrainskoi shkoly. Available at: http:/mon.gov.ua/activity/education/zagalna-serednya/ua-sch-2016/

[2] Bazovyi komponent doshkilnoi osvity. Available at: http://mon.gov.ua/activity/education/doshkilna/basicl/

[3] Dubaseniuk, O. A. (Ed.) (2009). Profesiina pedahohichna osvita: innovatsiini tekhnolohii ta metodyky. Zhytomyr: Vyd-vo ZhDU im. I. Franka, 504.

[4] Rybalko, L. S. (2007). Metodoloho-teoretychni zasady profesiino-pedahohichnoi samorealizatsii maibutnoho vchytelia (akmeolohichnyi aspekt). Zaporizhzhia: ZDMU, 442.

[5] Cherkashina, T. V.; Evtukh, N. B. (Ed.) (2014). Teoreticheskie i metodicheskie osnovy professional'nogo samosovershenstvovaniya prepodavatelya kak sub»ekta samopoznavatel'noy deyatel'nosti. Cherkassy: Izdatel Chabanenko Yu. A., 444. 
[6] Buriak, V. (2005). Rozvytok profesiino-pedahohichnykh yakostei u systemi bezperervnoi osvity. Vyshcha shkola, 2, 50-57.

[7] Lisina, L. O. (2011). Pidhotovka vchytelia v systemi pisliadyplomnoi pedahohichnoi osvity do konstruiuvannia navchalnykh tekhnolohii: teoretyko-metodolohichnyi aspekt. Zaporizhzhia: Plius 73, 471.

[8] Bielienka, H. V. (2011). Formuvannia profesiinoi kompetentnosti suchasnoho vykhovatelia doshkilnoho navchalnoho zakladu. Kyiv: Universytet, 320.

[9] Maslou, A. (2003). Motivatsiya i lichnost. Saint Petersburg: Izdatel’stvo «Piter», 352.

[10] Rodzhers, K. (2001). Stanovlenie lichnosti. Vzglyad na psikhoterapiyu. Moscow: EKSMO-Press, 416.

[11] Bekh, I. D. (2008). Vykhovannia osobystosti. Kyiv: Lybid, 848.

[12] Kh'ell, L., Zigler, D. (2002). Teorii lichnosti. Saint Petersburg: Izdatel'stvo «Piter», 608.

[13] Bekh, I. D. (2014). Innovatsiina vykhovna tekhnolohiia: sutnisni polozhennia ta shliakhy realizatsii. Pedahohichnyi visnyk, 4, 14-17.

[14] Bartkiv, O. (2010). Hotovnist pedahoha do innovatsiinoi profesiinoi diialnosti. Problemy pidhotovky suchasnoho vchytelia, 1, 52-58.

[15] Uruskyi, V. I. (2005). Formuvannia hotovnosti vchyteliv do innovatsiinoi diialnosti. Ternopil: TOKIPPO, 96.

\title{
COMPARISON OF TRADITIONAL AND INTERACTIVE TEACHING METHODS OF FIRST MEDICAL CARE FOR PHARMACISTS AT THE POST-GRADUATE STAGE OF TRAINING: RANDOMIZED, PROSPECTIVE STUDY
}

\author{
Mykhailo Omelchuk \\ Department of Surgery, Anesthesiology end intensive Care Postgraduate Education \\ Bogomolets National Medical University \\ 13 Shevctenko blvd., Kyiv, Ukraine, 01601 \\ omelchuk_mikhailo@ukr.net \\ Igor Sirenko \\ Department of Surgery, Anesthesiology end intensive Care Postgraduate Education \\ Bogomolets National Medical University \\ 13 Shevctenko blvd., Kyiv, Ukraine, 01601 \\ igor.sirenko.1988@gmail.com
}

\footnotetext{
Abstract

The aim of our work is to study and compare interactive and traditional teaching methods of pharmacists-interns for first medical care at the post-graduate educational stage.

To prove statistically or to deny advantages of interactive teaching methods, such as: simulation training, based on clinical cases, interactive lecture, close discussion, Peyton's 4 steps approach, positive criticism, based on two groups of pharmacists-interns, assessing the formed competence, stress-resistance and motivation for giving first medical care.

This is a prospective, randomized, pilot study with two groups of pharmacists-interns at studying at the internship from 2014 to 2017 year, based on the Institute of post-graduate education of the National medical university (NMU), named after O. O. Bogomolets, at one of learning stages - «Care at urgent states and acute intoxications". The participants were randomized and divided in two groups. There was formed the control group (CG), including 95 pharmacists-interns of 2014 year of admission, and in further the training was started according to the traditional methodology that doesn't provide interactive methods and simulation. The experimental group (EG) included 104 pharmacists-interns of 2015 year of admission that the program using interactive methods was elaborated for. Interactive methods used in the experimental group, included: simulation training, based on clinical scenarios, interactive lecture, close discussion, practical activity using Peyton's 4 steps approach, positive criticism. Activities lasted 12 hours
} 